Nat. Hazards Earth Syst. Sci., 19, 1319-1328, 2019

https://doi.org/10.5194/nhess-19-1319-2019

(C) Author(s) 2019. This work is distributed under

the Creative Commons Attribution 4.0 License.

\title{
Flood risk in a range of spatial perspectives - from global to local scales
}

\author{
Zbigniew W. Kundzewicz ${ }^{1,2,3}$, Buda Su ${ }^{1,4}$, Yanjun Wang ${ }^{1}$, Guojie Wang ${ }^{1}$, Guofu Wang ${ }^{4}$, Jinlong Huang ${ }^{1}$, and \\ Tong Jiang ${ }^{1}$ \\ ${ }^{1}$ Institute for Disaster Risk Management (iDRM), School of Geographical Sciences, \\ Nanjing University of Information Science and Technology (NUIST), Nanjing, China \\ ${ }^{2}$ Institute for Agricultural and Forest Environment, Polish Academy of Sciences, Poznań, Poland \\ ${ }^{3}$ Potsdam Institute for Climate Impact Research, Potsdam, Germany \\ ${ }^{4}$ National Climate Center, China Meteorological Administration, Beijing, China
}

Correspondence: Tong Jiang (jiangtong@ nuist.edu.cn) and Yanjun Wang (yjwang78@163.com)

Received: 9 November 2018 - Discussion started: 4 December 2018

Revised: 30 April 2019 - Accepted: 8 June 2019 - Published: 5 July 2019

\begin{abstract}
The present paper examines flood risk (composed of hazard, exposure, and vulnerability) in a range of spatial perspectives - from the global to the local scale. It deals with observed records, noting that flood damage has been increasing. It also tackles projections for the future, related to flood hazard and flood losses. There are multiple factors driving flood hazard and flood risk and there is a considerable uncertainty in our assessments, and particularly in projections for the future. Further, this paper analyses options for flood risk reduction in several spatial dimensions, from global framework to regional to local scales. It is necessary to continue examination of the updated records of flood-related indices, trying to search for changes that influence flood hazard and flood risk in river basins.
\end{abstract}

\section{Introduction}

River flooding is a major natural disaster, manifesting itself at a range of spatial and temporal scales - from floods on large international rivers conveying huge masses of water (cubic kilometres) lasting over weeks or months to potentially violent, destructive, and killing inundations in small, often urban basins lasting hours. It is estimated that, globally, floods constitute $43 \%$ of the total number of natural disasters and $47 \%$ of all weather-related disasters, affecting 2.3 billion people in 1995-2015, with total damage of the order of USD 662 billion. About 800 million people worldwide are currently liv- ing in flood-prone areas and about 70 million of those people are, on average, exposed to floods each year (UNISDR, 2015).

The nature of disastrous floods seems to have changed, in recent decades, with increasing frequency and amplitude of heavy precipitation and flash and urban floods, as well as acute riverine and coastal flooding. The climate track in flood hazard is complex and not ubiquitous (see Sect. 2). Urbanization and sealing of ground surface have significantly increased surface water runoff in many areas. In some countries, recurrent flooding of cropland has taken a heavy toll in terms of lost agricultural production, food shortages, interrupted food supplies, and undernutrition. However, some deleterious impacts of floods are preventable or at least can be reduced because of the opportunity of primary prevention through existing, and - in many places - affordable, technologies such as early warning systems and some flood defences, while awareness raising and education can also be effective in protecting people from adverse impact of floods.

The spatial perspective on floods ranges from a global view by multinational stakeholders, international organizations, reinsurance institutions, and think tanks, interested in global affairs to regional (group of countries and river basins which cross national borders, where $40 \%$ of the global population live and where transboundary water issues should be addressed), national, and subnational (river basins) scales. The local point of view is, for instance, that of the family of a person who lost their life in the flood, of a family 
that lost their house or workplace in the flood, or of persons responsible for local flood protection. The local scale pertains to the locality and community in flood-prone areas, where flood damage incurred and/or where implementation of a flood risk reduction measure is planned. The global consideration may include aggregation of observation records, model-based projections, and international policies aimed at flood risk reduction.

In the present paper, reviewing flood risk in a range of spatial perspectives (from global to local), we start from examination of observed records, noting that flood damage has been increasing. Further, we discuss projections for the future - flood hazard and flood losses, and then review flood risk reduction strategies, starting from the global framework to regional to local scales.

\section{Observed records - flood damage has been increasing}

European Academies' Science Advisory Council (see EASAC, 2018) presented the trends in the number of different types of natural catastrophes worldwide in 1980-2016 (with 1980 levels set at $100 \%$ ), based on the data from Munich Re NatCatSERVICE. The number of hydrological events (floods and mass movements) has increased much more than the number of geophysical, meteorological and climatic events. The number of hydrological events in an average year has now more than quadrupled since 1980 (exceeds $500 \%$ in some years). Global damage caused by "hydrological events", according to Munich Re, has been growing, albeit with strong inter-annual variability (Fig. 1). The named hurricanes, such as the most costly three that occurred in the North Atlantic in just 4 weeks, Harvey in August 2017 as well as Irma and Maria (September 2017), are counted as meteorological events. However, the vast majority of the total damage (approximately USD 95 billion) caused by Hurricane Harvey was related to flooding. This hurricane, which counts as the second-costliest on record (after Katrina), dropped record levels of rain that inundated the city of Houston, Texas, USA. If the damage caused by flooding related to Harvey were counted in Fig. 1, the year 2017 would likely be the outstanding one, with the highest flood damage ever.

Flood risk can be assumed to depend on flood hazard, flood exposure, and flood vulnerability, which, in turn, are driven by a complex interplay of climate system, terrestrial and hydrological system, and socio-economic system (Fig. 2). Kundzewicz et al. (2014) indicated that increasing exposure of population and assets has been primarily responsible for the recent increase in flood losses.

Economic losses in monetary units (adjusted for inflation and PPP, i.e. purchase power parity) caused by floods have been on the rise at any spatial scale. They are higher, in absolute terms, in industrialized countries, while relative economic losses expressed as a proportion of gross domestic product (GDP) and fatality rates are higher in less developed countries. This has grave security implications. This observation holds for natural disasters in general. From 1970 to 2008, over $95 \%$ of natural-disaster-related deaths occurred in developing countries (Field et al., 2012).

Typically, disaster losses associated with hydrological extremes can be well buffered in high-income countries (accounting for less than $0.1 \%$ of GDP), while being much higher, considerably exceeding $1 \%$ of GDP, in small exposed and less developed countries (Field et al., 2012).

Several factors may explain a perceived increase in flood risk:

- higher frequency and/or intensity of flood events;

- increased exposure of population and assets;

- increase in property value;

- generally, degraded awareness about natural risks, due to a less natural lifestyle;

- increased vulnerability; and

- improved and expanded reporting of disasters (sometimes called the "CNN effect").

We listed vulnerability increase as one of factors that may explain risk increase, but this holds for some areas only. In general, there is a significant decrease in vulnerability at the global scale (see Kundzewicz et al., 2014; Jongman et al., 2015), largely due to developments in China, and "vertical urbanization" in particular. Many examples of decreasing vulnerability at the local scale have been reported (e.g. Di Baldassarre et al., 2015; Mechler and Bouwer, 2015; Wind et al., 1999; Kreibich et al., 2017).

There are countries in the world (see Kundzewicz et al., 2014), where more than $10 \%$ of the population and/or more than $10 \%$ of the gross domestic product (GDP) were exposed to floods in an average year. In absolute terms, the highest number of people exposed was in India and Bangladesh (over 10 million each), and then in China, Vietnam, and Cambodia, while the highest amount of GDP exposed was in the USA and China (over USD 10 billion per year in each country), while in India and Bangladesh, it was nearly USD 10 billion. In relative terms, the highest percentage of people exposed was in Bangladesh and Cambodia (each over $10 \%$ of the total population), and then in Vietnam, while the highest relative share of economy exposed to floods was estimated in Cambodia and Bangladesh (over 10\% in each country), and then in Vietnam.

Dartmouth Flood Observatory (http://floodobservatory. colorado.edu/, last access: 28 June 2019) has been compiling information about large floods, worldwide, since 1985. A short list of the most deadly floods (including coastal surges) according to the Dartmouth Flood Observatory is presented in Table 1. Among the main causes of the most destructive 


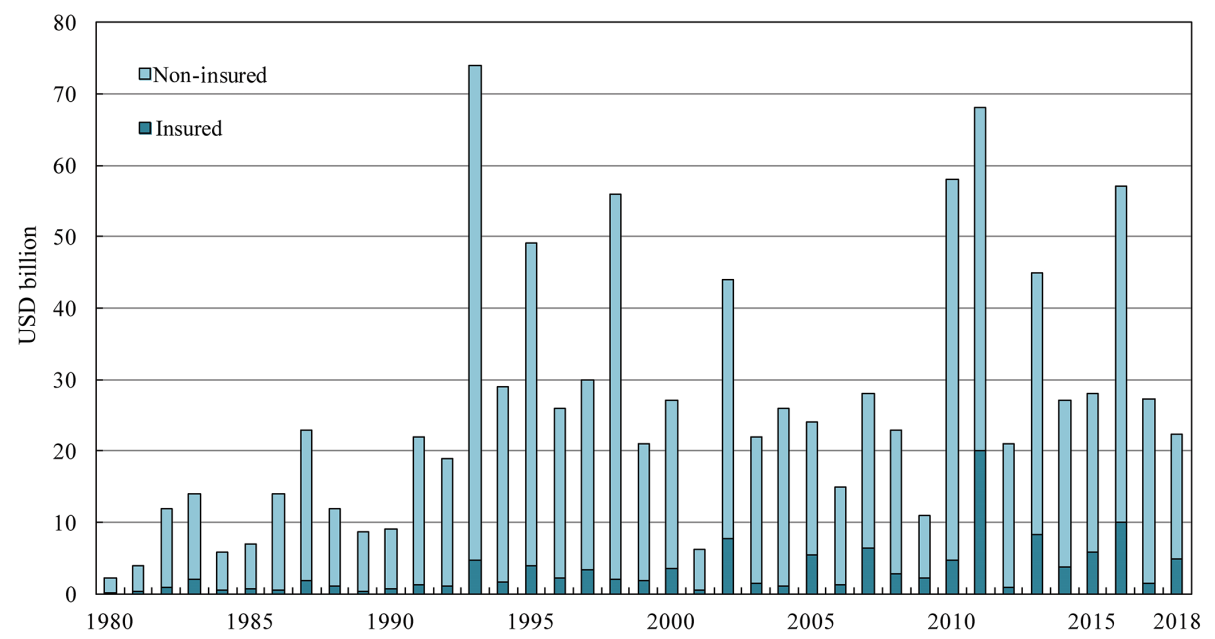

Figure 1. Global damage by hydrological events, in billions of US dollars (source: Munich Re NatCatSERVICE).

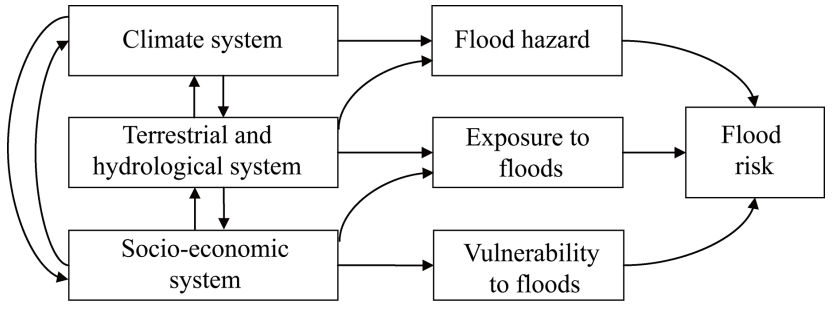

Figure 2. Conceptual sketch of components of flood risk and its drivers (after Kundzewicz et al., 2018c, modified).

floods (with more than 1000 fatalities per event) were tropical and extra-tropical cyclones, monsoonal rains, tropical storms, torrential rains, heavy rains, tsunamis, coastal surges, and typhoons. Floods with a heavy human toll were recorded in many locations in Asia (India, China, Bangladesh, Philippines, Afghanistan, Pakistan, Japan, Myanmar), Central and South America (Honduras, Venezuela, Dominican Republic, Haiti, Salvador, Nicaragua, Costa Rica), and Africa (Tanzania and Sudan).

Frequency and intensity of heavy precipitation have grown in many, but not all, areas of the globe. However, no gaugebased evidence has been found so far for a clear, widespread, and consistent change in the magnitude and/or frequency of river floods (see Kundzewicz et al., 2005; Madsen et al., 2014). Lins and Slack (1999) found that, hydrologically, the conterminous USA had been getting wetter, but less extreme. Later, they (Lins and Slack, 2005) confirmed the pattern of increasing discharge in the low to moderate range of river flows, without a concomitant increase in flooding. Relatively few trends in the annual maximum flow were detected. Hodgkins et al. (2017) examined climate-driven variability in the occurrence of major floods across North America and Europe, in minimally altered catchments (to eliminate major non-climatic effects), finding that the number of signifi- cant trends was approximately equal to the number expected due to chance alone. Shaw and Riha (2011) studied three watersheds in different physiographic regions of New York state, USA, and concluded that $20 \%$ or less of annual maximum streamflows were associated with the annual maximum rainfall events, another $20 \%$ with the annual maximum snowmelt events, and $60 \%$ with moderate rainfall amounts and very wet soil conditions. Noting that it has not been possible to find ubiquitous flood hazard changes in observation records in Europe, so far, Kundzewicz et al. (2018c) detected an increasing trend in the number of large floods, even if the natural variability dominates. It is likely that temporally varying connections exist between indices of climate variability and variability of the likelihood of destructive abundance of water. Blöschl et al. (2017) noted no "consistent climate change signal in flood magnitudes" in Europe, while Di Baldassarre et al. (2010) reported a similar finding for Africa.

Blöschl et al. (2017) found climate-induced patterns of change in observed flood timing in Europe, at the continental scale. They detected earlier spring snowmelt floods throughout northeastern Europe (warming-driven change), later winter floods around the North Sea and part of the Mediterranean coast (related to polar warming), and earlier winter floods in western Europe (reflecting advancement of soil moisture maxima). In contrast, Lins and Slack (2005) detected no systematic shift in the timing of the maximum flow in any US region on a monthly timescale.

\section{Projections for the future - flood hazard and flood damage}

Climate projections show ubiquitous warming for all seasons and most models project an increase in intense precipitation. Seneviratne et al. (2012) presented regional projections of 
Table 1. Six most deadly floods (including coastal surges) worldwide since 1985. Information from Dartmouth Flood Observatory.

\begin{tabular}{lllrl}
\hline Countries & $\begin{array}{l}\text { Flood } \\
\text { beginning }\end{array}$ & Flood end & $\begin{array}{r}\text { Dead } \\
\text { (thousand) }\end{array}$ & Main cause \\
\hline Thailand & 26 Dec 2004 & 29 Dec 2004 & 160 & Coastal surge \\
Bangladesh & 29 Apr 1991 & 10 May 1991 & 138 & Tropical cyclone \\
Burma & 3 May 2008 & 25 May 2008 & 100 & Tropical cyclone \\
Venezuela, Colombia & 15 Dec 1999 & 20 Dec 1999 & 20 & Brief torrential rain \\
Honduras, Panama & 24 Oct 1998 & 5 Nov 1998 & 11 & Brief torrential rain \\
India & 29 Oct 1999 & 12 Nov 1999 & 9.8 & Tropical cyclone \\
\hline
\end{tabular}

20 -year $24 \mathrm{~h}$ precipitation, noting increases over virtually all regions of the globe.

There have been several global studies of model-based projections of flood hazard, starting from Milly et al. (2002), who covered selected basins worldwide, and Hirabayashi et al. (2008), who covered the global scale. It is worthwhile to compare four more recent papers, published since 2013 by Hirabayashi et al. (2013), Dankers et al. (2014), Arnell and Gosling (2014), and Giuntoli et al. (2015). Table 2 presents assumptions made in the global projection endeavours that considerably differ among studies (there are also slightly different reference periods).

Projections by Hirabayashi et al. (2013) indicate that what used to be a 100-year flood in the control period in many areas is likely to occur much more frequently in the future, under changed climate, with a return period of 50 years and less. Hirabayashi et al. (2013) project an increase in hazard $\left(Q_{100}\right)$ in most of Asia (except for western Asia) and in particular eastwards of $80^{\circ} \mathrm{E}$. They also project flood hazard to increase in central Africa in the latitude range $20^{\circ} \mathrm{S}-10^{\circ} \mathrm{N}$ and in Central and South America from $20^{\circ} \mathrm{N}$ to $40^{\circ} \mathrm{S}$, as well as in the north of North America and on the east coast of the USA. For most of Europe, a decrease in flood hazard is projected. Results of Dankers et al. (2014) referring to a different index, $Q_{30}$ (30-year $5 \mathrm{~d}$ peak flow), are broadly similar to those reported by Hirabayashi et al. (2013) as to the direction of change, except for a large area of decrease in hazard in South America. In turn, Giuntoli et al. (2015) project more frequent days with high river flow conditions over much of the north, from $50^{\circ} \mathrm{N}$ northwards. However, over most of the area of continents, they projected rather small changes, with an absolute value less than $5 \%$ (i.e. from $-5 \%$ to $+5 \%$ ).

Studies of large-scale projections of changes in flood hazard illustrate a considerable degree of uncertainty. This is no wonder, as projections were determined for different assumptions (see Table 2). They may differ with respect to (see Kundzewicz et al., 2018a, b)

- greenhouse gas emissions scenarios (SRES, RCP);

- driving climate models, general circulation models (GCMs), and regional climate models (RCMs);

- downscaling techniques and bias correction methods;
- performance of large-scale hydrological models, i.e. global hydrological models (GHMs) and regional hydrological models (RHMs);

- climate and hydrological model resolution;

- time horizons of future projections;

- reference (historic) intervals;

- return period (recurrence interval) of concern;

- low-temperature effects, e.g. snow and ice component in models;

- general problems related to simulation of extremes and extreme value techniques applied to time series that are not long enough.

The implications of the changing flood hazard for human society depend on the size of the population at risk of flooding. Under the assumption of a fixed population (at the level of the scenario from 2005), it was projected that annual global flood exposure would increase by a factor of $4 \pm 3$ (under RCP2.6), $7 \pm 5$ (RCP4.5), $7 \pm 6$ (RCP6.0), and $14 \pm 10$ (RCP8.5) from the 20th to 21st century (Hirabayashi et al., 2013). However, such results have to be interpreted with caution, especially considering changing adaptation and risk reduction capacity.

Where both rain floods and snow floods (as well as icejam floods) can influence projections, relevant processes and different mechanisms have to be examined, for present and future conditions.

In addition, future flood risk in coastal zones will increase due to the sea level rise (Paprotny and Terefenko, 2017). Taking into account both the socioeconomic pathways and climate change but in absence of further investments in adaptation, Vousdoukas et al. (2018) projected the annual damage caused by coastal flooding in Europe to increase from the current EUR 1.25 billion to EUR 93-961 billion by the end of the 21 st century, and the exposed population to increase from the current level of 0.1 million to $1.52-3.65$ million. 
Table 2. Assumptions made in model-based global flood hazard projection studies.

\begin{tabular}{llllll}
\hline Paper & $\begin{array}{l}\text { Number of } \\
\text { climate } \\
\text { model } \\
\text { scenarios }\end{array}$ & $\begin{array}{l}\text { Number of } \\
\text { hydrological } \\
\text { models }\end{array}$ & $\begin{array}{l}\text { Variable } \\
\text { of interest }\end{array}$ & $\begin{array}{l}\text { Time } \\
\text { horizon of } \\
\text { concern }\end{array}$ & $\begin{array}{l}\text { Emission } \\
\text { scenario }\end{array}$ \\
\hline $\begin{array}{l}\text { Arnell and } \\
\text { Gosling (2014) }\end{array}$ & 21 GCMs & One: Mac-PDM.09 & $Q_{100}$ & $2050 \mathrm{~s}$ & SRES A1B \\
\hline $\begin{array}{l}\text { Dankers et al. } \\
(2014)\end{array}$ & Five GCMs & Nine GHMs & $Q_{30}$ & $2070-2099$ & RCP8.5 \\
\hline $\begin{array}{l}\text { Giuntoli et al. } \\
\text { (2015) }\end{array}$ & Five GCMs & Six GHMs & $\begin{array}{l}\text { Frequency } \\
\text { of high-flow } \\
\text { days }\end{array}$ & $2066-2099$ & RCP8.5 \\
\hline $\begin{array}{l}\text { Hirabayashi et } \\
\text { al. (2013) }\end{array}$ & 11 GCMs & $\begin{array}{l}\text { One CaMa-Flood } \\
\text { model }\end{array}$ & $\begin{array}{l}Q_{100} \\
2071-2100\end{array}$ & RCP8.5 \\
\hline
\end{tabular}

\section{Flood risk reduction - global framework}

Efforts on flood risk reduction are embedded in the general global framework, including major documents - Hyogo Framework for Action and Sendai Framework for Disaster Risk Reduction.

"Tragedies will continue to be repeated if we do not address water and disaster issues at all levels", stated Han Seung-soo, the founding chair of High-Level Experts and Leaders' Panel on Water and Disaster (HELP) (https: //www.unisdr.org/archive/58108, last access: 28 June 2019), while the UN special representative for disaster risk reduction, Mami Mizutori, remarked that floods which now account for half of all weather-related disasters highlight how disaster risk reduction is both a long-term development issue and a necessary strategy to prevent disasters and save lives in the short to medium term.

The World Conference on Disaster Reduction held in Hyogo, Japan, in 2005, promoting a strategic and systematic approach to reducing vulnerabilities and risks to hazards, adopted the Framework for Action 2005-2015, identifying ways of building the resilience of nations and communities to disasters (UNISDR, 2007).

Disaster loss has been on the rise with grave adverse consequences for the survival, dignity, and livelihood of people, particularly of the poor, and for hard-won development gains. Disaster risk is increasingly of global concern and a flood occurrence in one region can have an impact on risk in another one (e.g. via broken production links that manifested themselves during and after the 2011 Thailand flood). The Hyogo Framework identified specific gaps and challenges in the following main areas: organizational, legal, and policy frameworks in governance; risk identification, assessment, monitoring, and early warning; knowledge management and education; reduction of underlying risk factors; and preparedness for effective response and recovery.
Disaster risk reduction can be regarded as a cross-cutting issue in the realm of sustainable development and therefore an important element for the achievement of internationally agreed Millennium Development Goals.

The global plan for reducing disaster losses, the Sendai Framework for Disaster Risk Reduction, 20152030, was adopted by UN member states in 2015, at the Third UN World Conference on Disaster Risk Reduction in Sendai, Japan (https://www.unisdr.org/we/coordinate/ sendai-framework, last access: 28 June 2019). It is a voluntary, non-binding agreement aimed at a substantial reduction of disaster risk and losses in lives, livelihoods, health, and assets. It emphasizes the importance of risk-informed investment in critical infrastructure, including water facilities, to avoid the creation of new risk. Disaster risk reduction and prevention should be integrated in long-term national planning and education on disaster risk must be advanced. Recognizing the state's primary role to reduce disaster risk but also noting that responsibility should be shared with stakeholders, the Sendai Framework agreement, aiming to make a difference for poverty, health, and resilience, is the major document of the recent development agenda, embracing seven targets and four priorities for action.

The global targets include substantial reduction of mortality in flood disasters and the number of affected people and reduction of direct economic loss and damage to critical infrastructure as well as disruption of basic services (among them health and educational facilities), including enhancing resilience (recovery). The targets also include work on national and local disaster risk reduction strategies, international cooperation, and increasing the availability of and access to early warning systems (also dedicated to multiple hazards) and disaster risk information and assessments. Timelines for achieving these targets and reference intervals for measuring the progress were defined. 
The priorities for action refer to understanding of disaster risk in its dimensions of vulnerability, capacity, exposure of persons and assets, hazard characteristics, and the environment. Such knowledge can be used for risk assessment, as well as for various flood risk reduction strategies prevention, mitigation, preparedness and response, recovery and rehabilitation (see Dieperink et al., 2016; Driessen et al., 2016; Hegger et al., 2016; Kundzewicz et al., 2018b). Strengthening disaster risk governance at a range of levels (national, regional, and global) is another priority. Also investing in disaster risk reduction to enhance the economic, social, health, and cultural resilience of persons, communities, countries, and their assets as well as the environment is an identified priority. So is also enhancing disaster preparedness for effective response and "building back better". Disaster risk reduction has to be integrated into sustainable development measures.

Willner et al. (2018) computed the increase in flood protection that would be required worldwide for subnational administrative units, in order to maintain the historic high-end fluvial flood risk in the next 25 years. They found that most of the USA, central Europe, and northeast and west Africa, as well as large parts of India and Indonesia, require strong adaptation effort. For example, according to the results of this paper, flood protection needs to at least double over more than half of the United States within the next 2 decades.

However, the increase in flood protection levels to meet the requirements posed by Willner et al. (2018) would lead to having even more levees, which attract even more people and assets in flood-prone areas (that are often assumed to be perfectly safe by inhabitants). Since the seminal work of Gilbert White in the 1940s (White, 1945), many authors reported on the safe-development paradox, residual risk, and adverse levee effects (e.g. Kates et al., 2006; Ludy and Kondolf, 2012; Di Baldassarre et al., 2014). It has been shown that the introduction or reinforcement of structural protection measures is often associated with negative effects. Such effects include increasing exposure to flooding (Kates et al., 2006) and increasing vulnerability to flooding (as protected flood-prone areas are perceived as safer, so that inhabitants have fewer incentives to take individual precautionary measures; see Ludy and Kondolf, 2012). There is a social injustice effect - structural flood protection measures may alter the spatial distribution of risk in a way that affects less privileged social groups (Di Baldassarre et al., 2014). People in structurally protected areas are less willing to relocate from risky areas (Mård et al., 2018). Furthermore, levees that prevent natural inundation of floodplains also adversely affect biodiversity and ecological functions (Auerswald et al., 2019), e.g. via elimination of a "flood pulse".

\section{Flood risk reduction - from regional to local scales}

There is no doubt that flood risk has grown in many places and is likely to grow further in the future, due to a combina- tion of anthropogenic and climatic factors. Intense precipitation grows in the warming climate. However, reliable and detailed quantification of aggregate flood statistics is very difficult to obtain for the past to present and is virtually impossible to obtain for the future. Nevertheless, despite the lack of reliable projections, flood risk reduction endeavours have been carried out at a range of scales, from regional (multinational) to national, subnational, and local.

At the subcontinental scale, the European Union (EU) passed a dedicated directive, 2007/60/EC, on the assessment and management of flood risks (EU, 2007), which required all EU member states (28 at present) to identify areas at risk from flooding, to map the flood extent as well as assets and humans at risk in these areas, and to take adequate and coordinated measures to reduce this flood risk. This directive also reinforces the rights of the public to access information and to participate in the planning process. The directive aims to reduce and manage the risks that floods pose to human health, economic activity, environment, and cultural heritage. The directive required EU member states to establish flood risk management plans focused on prevention, protection, and preparedness by 2015.

Presence of people and wealth in flood-prone areas can be regarded like an illness. One can prevent flooding ("illness") by keeping the destructive water away from people and proceeding with flood defences. This cures the symptoms of the illness. One can also keep people away from the destructive water by way of zoning and banning floodplain development. This cures the source of the illness. However, it is also necessary to prepare for living with floods. This embraces flood mitigation - keeping water where it falls, flood preparation - forecasting, warning, and preparation for evacuation and post-flood recovery (see Dieperink et al., 2016; Driessen et al., 2016; Hegger et al., 2016; Nieland and Mushtaq, 2016, Kundzewicz et al., 2018b).

Since it is naïve to expect availability of trustworthy quantitative projections of future flood hazard (as some practitioners clearly do), in order to reduce flood risk, one should focus attention on identification of existing risk and vulnerability hotspots and improve the situation in areas where such hotspots occur (Kundzewicz et al., 2017).

The prerequisite for flood risk reduction is to examine long time series of reliable records on flood-related information. Koç and Thieken (2018) carried out a comparative national review of information on floods in Turkey from three sources: Turkey Disaster Database (TABB), the Emergency Events Database (EM-DAT), and the Global Active Archive of Large Flood Events - Dartmouth Flood Observatory. They found large mismatches in the flood data for Turkey, related to the number of events, the number of affected people, and the economic loss.

Flood protection, i.e. adaptation to huge variability of discharge, has been developed in China for 4 millennia, since the quasi-legendary Emperor Yu, who established the Xia dynasty, marking the beginning of Chinese civilization. He 
succeeded in taming a long-lasting and disastrous flood in the Yellow River basin by dredging and channelling the rivers to drain the floodwaters.

Flood protection has always been important in China, where hundreds of millions of people live in river valleys. Structural measures, both dikes and dams of different sizes, have a very long tradition in China (a term "hydraulic civilization" was coined by Wittfogel, 1956) and continue to play a vital role in flood prevention today, and in the foreseeable future. The multi-objective, massive Three Gorges Dam on the river Yangtze, the world's greatest engineering work, has flood protection as the principal objective. Many large reservoirs, also with flood protection as the main objective, have been built in China, with a total storage capacity in excess of $0.5 \times 10^{12} \mathrm{~m}^{3}$, accounting for over onefifth of the total estimated annual runoff from the land areas (Guo et al., 2004). Typically, water storage reservoirs serve multiple purposes: flood control, hydropower, irrigation, water supply, navigation, etc. The total number of large dams has increased significantly since 1960, when only five large dams (higher than $100 \mathrm{~m}$ ) existed in China. The number of large dams grew 10-fold in 2000 (Xu et al., 2010). In the second half of the 20th century, more than $200000 \mathrm{~km}$ of dikes have been strengthened for alleviating the impacts of floods in China (Zhang et al., 2002).

The level of expenditure on flood protection in China has grown considerably in recent decades. However, despite the massive efforts, it is becoming abundantly clear that complete flood control is not possible. Even if there are powerful levees along the rivers in China, they may not provide satisfactory protection of riparian habitats during large floods (see Kundzewicz and Xia, 2004). Recently, large flood damage has been increasingly occurring on medium- and small-size rivers. Hence, improvement of flood risk management is needed in the country and ambitious and vigorous attempts to improve flood preparedness have already been undertaken, by both structural ("hard") and non-structural ("soft") measures. The former refer to such defences as dikes, dams and flood control reservoirs, diversions, etc. The latter include implementing watershed management (source control), zoning, insurance, flood forecasting-warning systems, and awareness raising (Surminski et al., 2015; Nieland and Mushtaq, 2016; Adelekan and Asiyanbi, 2016). The coping capacities at a local level can influence the robustness of flood warning systems (Daupras et al., 2015).

In many countries, flood protection is distributed among several agencies, hence effective cooperation and communication among federal, state, and local stakeholders is essential. This is inherently difficult, but progress has been achieved in China in flood forecasting integration, data sharing, and collaborative problem solving. The China Meteorological Administration (CMA) collects observations of precipitation and other meteorological variables and prepares precipitation forecasts. The Ministry of Water Resources (MWR) of China collects hydrological observations (e.g. of river levels and discharges) and is responsible for flood forecasting and dissemination of the forecast. River basin commissions in China (altogether seven commissions, including the Yangtze River Basin Commission) are agencies of the MWR. The Flood Prevention Law of 2007 laid out principles and responsibilities for flood prevention planning in China. There is a national standard (GB50201-94) drafted by the Ministry of Water Resources and issued by the Ministry of Construction in 1994 dealing with flood return periods for different categories of location (Gemmer et al., 2011). In 2010, flood hazard mapping guidelines were published as a professional standard by the Ministry of Water Resources.

Gemmer et al. (2011) reviewed climate change adaptation in China, the National Climate Change Programme and China's White Paper "China's Policies and Actions for Addressing Climate Change". All 34 provinces of China produced a climate change adaptation plan, including flood risk reduction.

It is a well-established observation that occurrence of a disastrous flood event in a country or a region improves awareness and triggers investment in flood risk reduction as well as funding of relevant research. In fact, there are many case studies that report social learning effects, one of the findings being that the negative impact of an extreme flood tends to be lower if such an event occurs shortly after another one (e.g. in Jongman et al., 2015; Di Baldassarre et al., 2015; Mechler and Bouwer, 2015; Wind et al., 1999 and Kreibich et al., 2017). Di Baldassarre et al. (2015) show adaptation effects in study areas around the world, while Mechler and Bouwer (2015) noted a decreasing number of flood fatalities in Bangladesh over the past decades. Wind et al. (1999) reported that the economic losses of the 1995 Meuse River flooding were much lower than those in 1993, even though the magnitudes of the two events were comparable. Kreibich et al. (2017) illustrated the learning dynamics by way of multiregional, paired, flood event studies. However, sometimes deficiencies in learning show up. Marks and Thomalla (2017) studied consequences of the great 2011 flood in Thailand, noting that only minor efforts to reduce flood risk were made. The sociopolitical transformation needed to reduce system vulnerability has not occurred. The focus was on structural defences - building flood walls to reduce risk to large-scale enterprises, and this results in redistribution of risk to unprotected areas.

\section{Concluding remarks}

Many studies of flood hazard projections demonstrate the likely rise of flood hazard in the future. Plausible climate change scenarios indicate the possibility of increases in both the frequency and the magnitude of flooding events in many regions. Yet there has been no conclusive and general finding as to how climate change affects flood behaviour, in light 
of data observed so far, except some indications of regional changes in timing of floods observed in some areas, with increasing late autumn and winter floods (caused by rain) and fewer ice-jam-related floods, e.g. in Europe. The natural variability in observation records is overwhelming.

The flood risk depends on a combination of anthropogenic and natural factors, such as climate, land use, and population density and wealth (hence damage potential) in flood risk areas and development of flood defences. Owing to the growing population pressure, activities like deforestation, agricultural land expansion, urbanization (and increasing sealing of the ground surface), construction of roads, and reclamation of wetlands and lakes have been progressing. This has reduced the available water storage capacity in river basins, increased the value of the runoff coefficient, and aggravated flood hazard and flood risk. Flood potential has ubiquitously increased - there is simply more to lose.

There are multiple factors driving flood hazard and flood risk and there is a considerable uncertainty in our assessments, and in particular projections for the future. In many places flood risk is likely to grow, due to a combination of anthropogenic and climatic factors. However, in general, it is difficult to disentangle the climatic change component in maximum river flow or flood hazard records from strong natural variability and direct, synthetic, environmental changes. There is a large difference between flood hazard projections obtained by using different scenarios and different models. Therefore, one should be careful with flat-rate statements on changes in flood hazard and flood risk, and on climate change impact in particular. The impact of climate forcing on flood risk is complex and depends on the flood generation mechanism. Indeed, higher and more intense precipitation has already been observed in many (but not all) areas of the globe and this trend is expected to strengthen in the warmer world, directly impacting flood risk. Therefore, common-sense changes to design rules, aimed at flood risk reduction, have been introduced in some countries of Europe, based more on precautionary principle rather than on robust science. The design flood was adjusted upward in light of projections for the warmer climate.

However, it is a robust statement that, in general, today's climate models are still not good enough at producing local climate extremes due to, inter alia, inadequate (coarse) resolution. There is hope that, with improving resolution, models will be able to grasp details of extreme events in a more accurate and reliable way (Kundzewicz and Schellnhuber, 2004).

It is necessary to continue examination of the updated records of flood-related indices, trying to search for changes that influence flood hazard and flood risk in river basins. Possibly, there have been and will continue to be changes in intense precipitation, changes in cyclone track, changes in land use, and changes in exposure and vulnerability. Early detection and attribution of changes at any spatial scale would be of vast practical importance.
Data availability. The co-authors used publicly available data from Munich Re NatCatSERVICE and from Dartmouth Floods Observatory.

Author contributions. ZWK and JT conceived the study, ZWK drafted the paper, and all co-authors jointly worked on enriching and developing the draft, also in reaction to reviewers' recommendations.

Competing interests. The authors declare that they have no conflict of interest.

Acknowledgements. This study was supported by the National Key Research and Development Program of China MOST (2018FY100501) and a bilateral cooperation project between the Natural Science Foundation of China and the Pakistan Science Foundation (41661144027). The CMA Special Fund on Climatic Change Research (CCSF 201810, CCSF 201924) offered a PhD student job. The authors are thankful for the support by the High-level Talent Recruitment Program of the Nanjing University of Information Science and Technology (NUIST). Thanks are also due to Munich Re NatCatSERVICE for provision of global flood loss data. The review by the two anonymous referees, who provided many constructive and useful comments, proved to be valuable and allowed us to enrich this paper.

Review statement. This paper was edited by Maria-Carmen Llasat and reviewed by two anonymous referees.

\section{References}

Adelekan, I. O. and Asiyanbi, A. P.: Flood risk perception in floodaffected communities in Lagos, Nigeria, Nat. Hazards, 80, 445469, 2016.

Arnell, N. W. and Gosling, S. N.: The impacts of climate change on river flood risk at the global scale, Climatic Change, 134, 387401, https://doi.org/10.1007/s10584-014-1084-5, 2014.

Auerswald, K., Moyle, P., Seibert, S. P., and Geist, J.: HESS Opinions: Socio-economic and ecological trade-offs of flood management-benefits of a transdisciplinary approach, Hydrol. Earth Syst. Sci., 23, 1035-1044, https://doi.org/10.5194/hess-231035-2019, 2019.

Blöschl, G., Hall, J., Parajka, J., Perdigao, R. A. P., Merz, B., Arheimer, B., Aronica, G. T., Bilibashi, A., Bonacci, O., Borga, M., Canjevac, I., Castellarin, A., Chirico, G. B., Claps, P., Fiala, K., Frolova, N., Gorbachova, L., Gul, A., Hannaford, J., Harrigan, S., Kireeva, M., Kiss, A., Kjeldsen, T. R., Kohnova, S., Koskela, J. J., Ledvinka, O., Macdonald, N., MavrovaGuirguinova, M., Mediero, L., Merz, R., Molnar, P., Montanari, A., Murphy, C., Osuch, M., Ovcharuk, V., Radevski. I., Rogger. M., Salinas, J. L., Sauquet, E., Šraj, M., Szolgay, J., Viglione, A., Volpi, E., Wilson, D., Zaimi, K., and Živkovic, N.: Changing 
climate shifts timing of European floods, Science, 357, 588-590, https://doi.org/10.1126/science.aan2506, 2017.

Dankers, R., Arnell, N. W., Clark, D. B., Falloon, P. D., Fekete, B. M., Gosling, S. N., Heinke, J., Kim, H., Masaki, Y., Satoh, Y., Stacke, T., Wada, Y., and Wisser, D.: First look at changes in flood hazard in the inter-sectoral impact model intercomparison project ensemble, P. Natl. Acad. Sci. USA, 111, 3257-3261, https://doi.org/10.1073/pnas.1302078110, 2014.

Daupras, F., Antoine, J. M., Becerra, S., and Peltier, A.: Analysis of the robustness of the French flood warning system: a study based on the 2009 flood of the Garonne River, Nat. Hazards, 75, 215-241, 2015.

Di Baldassarre, G., Montanari, A., Lins, H., Koutsoyiannis, D., Brandimarte, L., and Blöschl, G.: Flood fatalities in Africa: from diagnosis to mitigation, Geophys. Res. Lett., 37, L22402, https://doi.org/10.1029/2010GL045467, 2010.

Di Baldassarre, G., Kemerink, J. S., Kooy, M., and Brandimarte, L.: Floods and societies: the spatial distribution of water-related disaster risk and its dynamics, Wiley Interdisciplin, Rev,: Water, 1, 133-139, 2014.

Di Baldassarre, G., Viglione, A., Carr, G., Kuil, L., Yan, K., Brandimarte, L., and Blöschl, G.: Perspectives on socio-hydrology: Capturing feedbacks between physical and social processes, Water Resour. Res., 51, 4770-4781, 2015.

Dieperink, C., Hegger, D. L. T., Bakker, M. H. N., Kundzewicz, Z. W., Green, C., and Driessen, P. P. J.: Recurrent governance challenges in the implementation and alignment of flood risk management strategies: a review, Water Resour. Manage., 30, 44674481, https://doi.org/10.1007/s11269-016-1491-7, 2016.

Driessen, P. P. J., Hegger, D. L. T., Bakker, M. H. N., Rijswick, H. F. M. W. V., and Kundzewicz, Z. W.: Toward more resilient flood risk governance, Ecol. Soc., 21, 53, https://doi.org/10.5751/ES08921-210453, 2016.

EASAC - European Academies' Science Advisory Council: Extreme weather events in Europe, Preparing for climate change adaptation: an update on EASAC's 2013 study, available at: https://easac.eu/fileadmin/PDF_s/reports_statements/ Extreme_Weather/EASAC_Statement_Extreme_Weather_ Events_March_2018_FINAL.pdf (last access: 28 June 2019), 2018.

EU - European Union: Directive 2007/60/EC of the European parliament and of the council of 23 October 2007 on the assessment and management of flood risks, Offic. J. Europ. Un., L288, 2734, 2007.

Field, C. B., Barros, V., Stocker, T. F., Qin, D., Dokken, D. J., Ebi, K. L., Mastrandrea, M. D., Mach, K. J., Plattner, G. K., Allen, S. K., Tignor, M., and Midgley, P. M.: Managing the risks of extreme events and disasters to advance climate change adaptation, in: Special Report of Working Groups I and II of the Intergovernmental Panel on Climate Change (IPCC), Cambridge University Press, Cambridge, UK, 2012.

Gemmer, M., Wilkes, A., and Vaucel, L. M.: Governing climate change adaptation in the EU and China: An analysis of formal institutions, Adv. Clim/ Change Res/, 2, 1-11, 2011.

Giuntoli, I., Vidal, J. P., Prudhomme, C., and Hannah, D. M.: Future hydrological extremes: the uncertainty from multiple global climate and global hydrological models, Earth Syst. Dynam., 6, 267-285, https://doi.org/10.5194/esd-6-267-2015, 2015.
Guo, S., Zhang, H., Chen, H., Peng, D., Liu, P., and Pang, B.: A reservoir flood forecasting and control system for China, Hydrolog. Sci. J., 49, 959-972, 2004.

Hegger, D. L. T., Driessen, P. P. J., Wiering, M., Rijswick, H. F. M. W., Kundzewicz, Z. W., Matczak, P., Crabbé, A., Raadgever, G. T., Bakker, M. H. N., Priest, S. J., Larrue, C., and Ek, K.: Toward more flood resilience: Is a diversification of flood risk management strategies the way forward?, Ecol. Soc., 21, 52-71, https://doi.org/10.5751/ES-08854-210452, 2016.

Hirabayashi, Y, Kanae, S., Emori, S., Oki, T., and Kimoto, M.: Global projections of changing risks of floods and droughts in a changing climate, Hydrolog. Sci. J., 53, 754-772, https://doi.org/10.1623/hysj.53.4.754, 2008.

Hirabayashi, Y., Mahendran, R., Koirala, S., Konoshima, L., Yamazaki, D., Watanabe, S., Kim, H., and Kanae, S.: Global flood risk under climate change, Nat. Clim. Change, 3, 816-821, https://doi.org/10.1038/nclimate1911, 2013.

Hodgkins, G. A., Whitfield, P. H., Burn, D. H., Hannaford, J., Renard, B., Stahl, K., Fleig, A. K., Madsen, H., Mediero, L., Korhonen, J., Murphy, C., and Wilson, D.: Climatedriven variability in the occurrence of major floods across North America and Europe, J. Hydrol., 552, 704-717, https://doi.org/10.1016/j.jhydrol.2017.07.027, 2017.

Jongman, B., Winsemius, H. C., Aerts, J. C., de Perez, E. C., van Aalst, M. K., Kron, W., and Ward, P. J.: Declining vulnerability to river floods and the global benefits of adaptation, $\mathrm{P}$. Natl. Acad. Sci. USA, 112, E2271-E2280, 2015.

Kates, R. W., Colten, C. E., Laska, S., and Leatherman, S. P.: Reconstruction of New Orleans after Hurricane Katrina: A research perspective, P. Natl. Acad. Sci. USA, 103, 14653-14660, 2006.

Koç, G. and Thieken, A. H.: The relevance of flood hazards and impacts in Turkey: What can be learned from different disaster loss databases?, Nat. Hazards, 91, 375-408, 2018.

Kreibich, H., Di Baldassarre, G., Vorogushyn, S., Aerts, J. C., Apel, H., Aronica, G. T., Arnbjerg-Nielsen, K., Bouwer, L. M., Bubeck, P., Caloiero, T., Chinh Do, T., Cortès, M., Gain, A. K., Giampá, V., Kuhlicke, C., Kundzewicz, Z. W., Carmen Llasat, M., Mård, J., Matczak, P., Mazzoleni, M., Molinari, D., Dung, N. V., Petrucci, O., Schröter, K., Slager, K., Thieken, A. H., Ward, P. J., and Merz, B.: Adaptation to flood risk: Results of international paired flood event studies, Earth's Future, 5, 953-965, 2017.

Kundzewicz, Z. W. and Schellnhuber, H. J.: Floods in the IPCC TAR perspective, Nat. Hazards, 31, 111-128, 2004.

Kundzewicz, Z. W. and Xia, J.: Towards an improved flood preparedness system in China, Hydrolog. Sci. J., 49, 941-944, 2004. Kundzewicz, Z. W., Graczyk, D., Maurer, T., Pińskwar, I., Radziejewski, M., Svensson, C., and Szwed, M.: Trend detection in river flow series: 1. Annual maximum flow, Hydrolog. Sci. J., 50, 797-810, 2005.

Kundzewicz, Z. W., Kanae, S., Seneviratne, S. I., Handmer, J., Nicholls, N., Peduzzi, P., Mechler, R., Bouwer, L. M., Arnell, N., Mach, K., Muir-Wood, R., Brakenridge, G. R., Kron, W., Benito, G., Honda, Y., Takahashi, K., and Sherstyukov, B.: Flood risk and climate change: global and regional perspectives, Hydrolog. Sci. J., 59, 1-28, 2014.

Kundzewicz, Z. W., Krysanova, V., Dankers, R., Hirabayashi, Y., Kanae, S., Hattermann, F. F., Huang, S., Milly, P. C. D., Stoffel, M., Driessen, P. P. J., Matczak, P., Quevauviller, P., and Schellnhuber, H. J.: Differences in flood hazard projections in 
Europe - their causes and consequences for decision making, Hydrolog. Sci. J., 62, 1-14, 2017.

Kundzewicz, Z. W., Krysanova, V., Benestad, R. E., Hov, Ø., Piniewski, M., and Otto, I. M.: Uncertainty in climate change impacts on water resources, Environ. Sci. Policy, 79, 1-8, 2018a.

Kundzewicz, Z. W., Hegger, D. L. T., Matczak, P., and Driessen, P. P. J.: Flood risk reduction: structural measures and diverse strategies, P. Natl. Acad. Sci. USA, 115, 12321-12325, 2018b.

Kundzewicz, Z. W., Pińskwar, I., and Brakenridge, G. R.: Changes in river flood hazard in Europe: a review, Hydrol. Res., 49, 294 302, https://doi.org/10.2166/nh.2017.016, 2018c.

Lins, H. F. and Slack, J. R.: Streamflow trends in the United States, Geophys. Res. Lett., 26, 227-230, 1999.

Lins, H. F. and Slack, J. R.: Seasonal and regional characteristics of U.S. streamflow trends in the United States from 1940 to 1999 , Phys. Geogr., 26, 489-501, 2005.

Ludy, J. and Kondolf, G. M.: Flood risk perception in lands "protected" by 100-year levees, Nat. Hazards, 61, 829-842, 2012.

Madsen, H., Lawrence, D., Lang, M., Martinkova, M., and Kjeldsen T. R.: Review of trend analysis and climate change projections of extreme precipitation and floods in Europe, J. Hydrol., 519, 3634-3650, 2014.

Mård, J., Di Baldassarre, G., and Mazzoleni, M.: Nighttime light data reveal how flood protection shapes human proximity to rivers, Sci. Adv., 4, eaar5779, https://doi.org/10.1126/sciadv.aar5779, 2018.

Marks, D. and Thomalla, F.: Responses to the 2011 floods in Central Thailand: Perpetuating the vulnerability of small and medium enterprises?, Nat. Hazards, 87, 1147-1165, 2017.

Mechler, R. and Bouwer, L. M.: Understanding trends and projections of disaster losses and climate change: is vulnerability the missing link?, Climatic Change, 133, 23-35, 2015.

Milly, P. C. D., Wetherald, R. T., Dunne, K. A., and Delworth, T. L.: Increasing risk of great floods in a changing climate, Nature, 415, 514-517, 2002.

Nieland, C. and Mushtaq, S.: The effectiveness and need for flash flood warning systems in a regional inland city in Australia, Nat. Hazards, 80, 153-171, 2016.

Paprotny, D. and Terefenko, P.: New estimates of potential impacts of sea level rise and coastal floods in Poland, Nat. Hazards, 85, 1249-1277, 2017.

Seneviratne, S. I., Nicholls, N., Easterling, D., Goodess, C., Kanae, S., Kossin, J., Luo, Y., Marengo, J., McInnes, K., Rahimi, M., Reichstein, M., Sorteberg, A., Vera, C., and Zhang, X.: Changes in climate extremes and their impacts on the natural physical environment, in: Managing the risks of extreme events and disasters to advance climate change adaptation, A special report of working groups I and II of the Intergovernmental Panel on Climate Change (IPCC), edited by: Field, C. B., Barros, V., Stocker, T. F., Qin, D., Dokken, D. J., Ebi, K. L., Mastrandrea, M. D., Mach, K. J., Plattner, G. K., Allen, S. K., Tignor, M., and Midgley, P. M., Cambridge University Press, Cambridge, and New York, NY, 2012.
Shaw, S. B. and Riha, S. J.: Assessing possible changes in flood frequency due to climate change in mid-sized watersheds in New York State, USA, Hydrol. Process., 25, 2542-2550, 2011.

Surminski, S., Aerts, J. C. J. H., Botzen, W. J. W., Hudson, P., Mysiak, J., and Pérez-Blanco, C. D.: Reflections on the current debate on how to link flood insurance and disaster risk reduction in the European Union, Nat. Hazards, 79, 1451-1479, 2015.

UNISDR - The United Nations Office for Disaster Risk Reduction: Hyogo Framework for action 2005-2015: Building the resilience of nations and communities to disasters, available at: https://www.unisdr.org/files/ 1037_hyogoframeworkforactionenglish.pdf (last access: 28 June 2019), 2007.

UNISDR - The United Nations Office for Disaster Risk Reduction: The human cost of weather-related disasters 1995-2015, available at: https://www.unisdr.org/files/ 46796_cop21weatherdisastersreport2015.pdf (last access: 28 June 2019), 2015.

Vousdoukas, M. I., Mentaschi, L., Voukouvalas, E., Bianchi, A., Dottori, F., and Feyen, L.: Climatic and socioeconomic controls of future coastal flood risk in Europe, Nat. Clim. Change, 8, 776780, 2018.

White, G. F.: Human Adjustments to Floods, Department of Geography, Research Paper No. 29, Department of Geography, University of Chicago, Chicago, 225 pp., 1945.

Willner, S. N., Levermann, A., Zhao, F., and Frieler, F.: Adaptation required to preserve future high-end river flood risk at present levels, Sci. Adv., 4, eaao1914, https://doi.org/10.1126/sciadv.aao1914, 2018.

Wind, H. G., Nierop, T. M., de Blois, C. J., and de Kok, J. L. Analysis of flood damages from the 1993 and 1995 Meuse floods, Water Resour. Res., 35, 3459-3465, 1999.

Wittfogel, K. A.: The hydraulic civilization: Man's role in changing the Earth, University of Chicago Press, Chicago, IL, USA, 1956.

$\mathrm{Xu}, \mathrm{K}$., Milliman, J. D., and Xu, H.: Temporal trend of precipitation and runoff in major Chinese Rivers since 1951, Global Planet. Change, 73, 219-232, 2010.

Zhang, J. Q., Zhou, C. H., Xu, K. Q., and Watanabe, M.: Flood disaster monitoring and evaluation in China, Environ. Hazards, 4, 33-43, 2002. 